\title{
PENGARUH PENAMBAHAN TULANGAN BAMBU TERHADAP KUAT LENTUR PANEL SEMEN ECENG GONDOK
}

\section{The Influence of The Addition of Bamboo Reinforcement against Bending Strength Cement Panel Hyacinth}

\author{
Ahmad Fitri Sujatmiko ${ }^{1}$, Sri Murni Dewi², Devi Nuralinah ${ }^{3}$ \\ ${ }^{1}$ Jurusan Sipil Fakultas Teknik Universitas Muhammadiyah Malang \\ Jl. Raya Tlogomas No.246, Malang (0341) 464318 \\ 2,3 Jurusan Sipil Fakultas Teknik Universitas Brawijaya Malang \\ Jl. M.T. Haryono No. 167, Malang-65145, Jawa Timur
}

\begin{abstract}
This study is a follow-utilization of water hyacinth as a building material wall panel (Emen wall). From previous studies, physical properties, mechanical, acoustic and endurance burn this material meets the standards of building materials PUBI 1982 and ISO and ASTM C423-90a 03-6861.1-2002. In this study, the variable still is a variation of the test specimen without reinforcement with reinforcement of bamboo and bamboo in the form of a model variation of the beam section size $(15 \times 20 \mathrm{~cm})$ and sectional plates $(5 \times 15 \mathrm{~cm})$. While the independent variable is in the form of bending strength and deflection in the test specimen. The results showed the effect of bamboo reinforcement against bending strength cement panel hyacinth. On the test object model of the beam section with bamboo reinforcement ratio $\rho=0, \rho=0.006$ and $\rho=0.01$, powerful bending $P=24 \mathrm{~kg}, P=59 \mathrm{~kg}$ and $P=72 \mathrm{~kg}$. To model the cross section of the plate with a bamboo reinforcement ratio $\rho=0, \rho=0.017$ and $\rho=0.025$, stronger bending is $P=3,33 \mathrm{~kg}$, $P=16,33 \mathrm{~kg}$ and $P=21,83 \mathrm{~kg}$.
\end{abstract}

Keywords: flexural strength, cement panel hyacinth, bamboo reinforcement

\begin{abstract}
Abstrak
Penelitian ini merupakan penelitian lanjutan pemanfaatan eceng gondok sebagai material bahan bangunan dinding panel (emen wall). Dari kajian terdahulu, sifat fisik, mekanik, akustik dan ketahanan bakar material ini memenuhi standar bahan bangunan PUBI 1982 dan SNI 03-6861.12002 serta ASTM C423-90a. Pada penelitian ini, variabel tetap adalah variasi benda uji tanpa tulangan bambu dan dengan tulangan bambu dalam variasi ukuran berupa model penampang balok $(15 \times 20 \mathrm{~cm})$ dan penampang plat $(5 \times 15 \mathrm{~cm})$. Sedangkan variabel bebas adalah berupa kuat lentur dan defleksi pada benda uji. Hasil penelitian menunjukkan adanya pengaruh penambahan tulangan bambu terhadap kuat lentur panel semen eceng gondok. Pada benda uji model penampang balok dengan rasio tulangan bambu $\rho=0, \rho=0,006$ dan $\rho=0,01$ kuat lenturnya adalah $\mathrm{P}=24 \mathrm{~kg}, \mathrm{P}=59 \mathrm{~kg}$ dan $\mathrm{P}=72 \mathrm{~kg}$. Untuk model penampang plat dengan rasio tulangan bambu $\rho=0, \rho=0,017$ dan $\rho=0,025$ kuat lenturnya adalah $P=3,33 \mathrm{~kg}, P=16,33 \mathrm{~kg}$ dan $P=21,83 \mathrm{~kg}$.
\end{abstract}

Kata kunci: kuat lentur, panel semen eceng gondok, tulangan bambu

\section{PENDAHULUAN}

Eceng gondok/Water Hyacinth (Eichhornia crassipes (mart) solm) merupakan tumbuhan air yang sulit diberantas (gulma) dengan kapasitas produksi mencapai 4-5 ton per ha / tahun (Supriyanto, 2000).

Dari kajian awal diketahui bahwa tanaman eceng gondok memiliki kadar serat sedang dengan panjang $1,75-2,12 \mathrm{~mm}$ dan berdiameter 11,15 - 11,65 $\mu \mathrm{m}$ pada batangnya, hal ini menjadikan serat eceng gondok sesuai untuk bahan baku mentah pada industri panel semen dan papan serat lainnya (Joedodibroto, 2001). Hal ini juga sesuai dengan Peraturan Umum Bahan Bangunan Indonesia (PUBI tahun 1982), bahwa serat batang dari tanaman eceng gondok bisa digunakan sebagai bahan baku campuran industri panel papan semen. 
Hal-hal yang bersifat khusus dari material panel papan semen ditentukan oleh dua bagian utama yaitu kayu dan semen. Bahan Kayu mempunyai sifat bahan yang ringan dan elastis serta mudah untuk dikerjakan. Adapun bahan semen mempunyai sifat yang tahan terhadap api dan tahan terhadap air serta jamur dan rayap. Gabungan dari kedua sifat tersebut menjadikan material panel papan semen eceng gondok ini mempunyai beberapa keunggulan bahan yang tidak dimiliki material lain.

Penelitian tentang bambu oleh Morisco (1994-1999) didapatkan kenyataan bahwa kuat tarik bambu sangat tinggi. Sebagai perbandingan pada tulangan baja pada beton mempunyai tegangan leleh sebesar $240 \mathrm{Mpa}$, dari pengujian tegangan tarik berbagai jenis bambu adalah sebagai berikut: bambu ori 417 Mpa, bambu petung $285 \mathrm{Mpa}$, bambu hitam 237 Mpa dan bambu tutul $286 \mathrm{Mpa}$.

Dari latar belakang ini, maka dibuat sebuah material bahan bangunan alternatif berupa dinding panel semen eceng gondok (emen wall) dengan penambahan tulangan bamboo sebagai perkuatan lentur. Pada kajian ini akan difokuskan pada pemeriksaan kekuatan lentur panel semen eceng gondok perkuatan tulangan bambu dalam skala laboratorium.

\section{METODE PENELITIAN}

\section{Variabel Penelitian}

Dalam penelitian ini, variabel tetap adalah variasi jumlah tulangan bambu dalam panel semen eceng gondok. Sedangkan variabel bebas adalah kuat lentur berupa kapasitas penampang dalam bentuk $\mathrm{P}$ teoritis.

Untuk benda uji elemen balok (Model A), variabel tetap berupa variasi benda uji ke-1 tanpa tulangan $\rho=0$, benda uji ke-2 menggunakan tulangan sejumlah $\rho=0,006$ dan benda uji ke- 3 dengan tulangan $\rho=0,01$.

Untuk benda uji elemen plat (Model B), variabel tetap berupa variasi benda uji ke-1 tanpa tulangan $\rho=0$, benda uji ke-2 menggunakan tulangan sejumlah $\rho=0,017$ dan benda uji ke-3 dengan tulangan $\rho=0,025$.

\section{Pembuatan Benda Uji}

Benda uji panel panel semen eceng gondok dibuat dengan komposisi eceng gondok : semen adalah $1: 2,5$ perbandingan berat. Benda uji dibuat menjadi 2 model yaitu: model A berupa balok dengan dimensi $15 \times 20 \times 70 \mathrm{~cm}$ dan model $B$ berupa plat panel dengan dimensi $15 \times 5 \times 70 \mathrm{~cm}$. Kedua model akan diberi variasi dengan penambahan tulangan dari bambu diameter kotak $\Phi 8 \mathrm{~mm}$. Masing-masing variasi dibuat sebanyak 3 sampel.

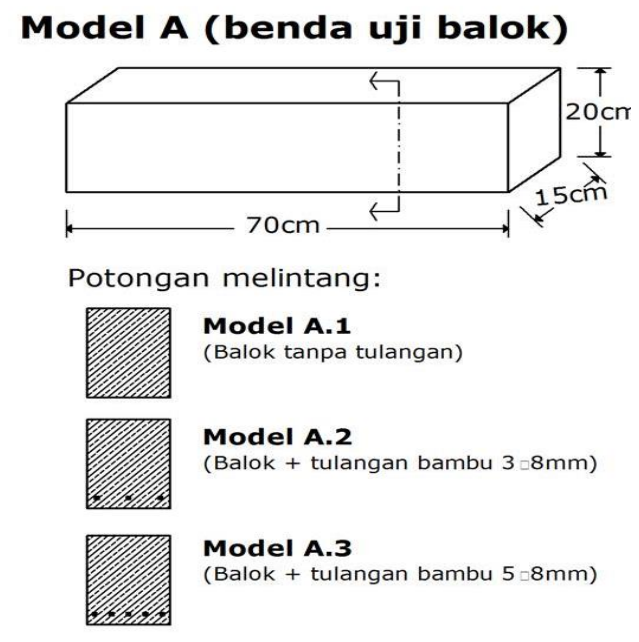

Model B (benda uji panel plat )

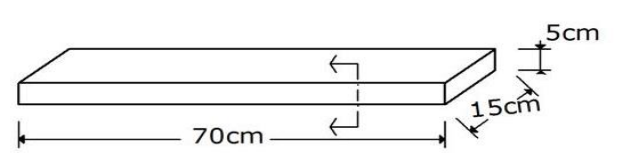

Potongan melintang:

Model B.1
(Plat tanpa tulangan)

Model B.2

(Plat + tulangan bambu $8-100 \mathrm{~mm}$ )

Model B.3

(Plat + tulangan bambu $-8-50 \mathrm{~mm}$ )

Gambar 1. Sketsa benda uji

\section{Persamaan yang digunakan}

Untuk menghitung kekakuan lentur benda uji, menggunakan standar Pd M-18-2000-3 (Metode Pengujian Lentur Panel Kayu Struktural). Dari hasil pengujian, didapat data beban $(\mathrm{P})$ dan lendutan $(\Delta)$. Kekakuan lentur benda uji didapatkan dengan persamaan berikut

$$
\mathrm{EI}=\left(\mathrm{L}^{3} / 48\right) \cdot(\mathrm{P} / \Delta)
$$

Dimana:

EI = Modulus elastisitas $\mathrm{x}$ Momen inersia

$\mathrm{P} / \Delta=$ kemiringan kurva beban-lendutan

$\mathrm{L} \quad=$ Panjang bentang $(\mathrm{mm})$ 


\section{Perhitungan Kuat Lentur}

Analisis lentur balok papan semen eceng gondok bertulangan bambu yang digunakan pada penelitian ini mengacu pada pendekatan keseimbangan antara gaya tekan beton $(C)$ dan gaya tarik pada tulangan bambu $(\mathrm{T})$ yang harus terpenuhi. Gaya tarik pada tulangan bambu $(\mathrm{T})$ diperoleh dari hasil perkalian tegangan lekatan (pull out) dengan luas geser tulangan. Berdasarkan hasil penelitian terdahulu, keruntuhan balok bertulangan bambu diakibatkan oleh hilangnya lekatan antara tulangan bambu dan mortar.

Skema pendekatan keseimbangan antara gaya tarik tulangan bambu (T) dan gaya tekan material papan semen eceng gondok (C) diuraikan seperti pada gambar berikut.

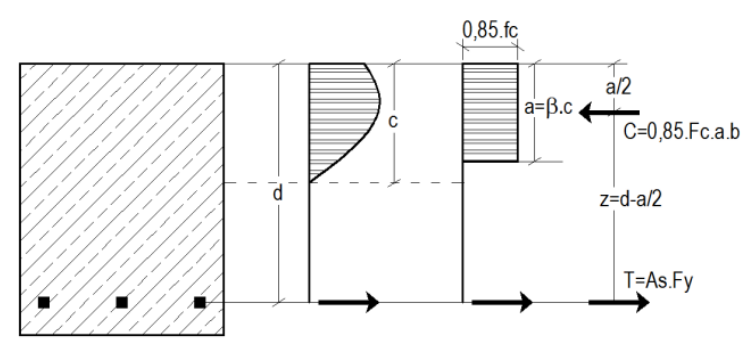

Gambar 2. Skema diagram penampang

Dalam penelitian ini ada dua perlakuan benda uji yaitu benda uji tanpa tulangan bambu dan benda uji dengan tulangan bambu.

Untuk benda uji tanpa tulangan bambu, $P$ teoritis diturunkan dari persamaan berikut

$$
F l t=\frac{M \cdot y}{I}
$$

Dimana ;

$$
\begin{aligned}
& \mathrm{M}=\text { Momen }=1 / 4 . \mathrm{P} . \mathrm{L} \\
& \mathrm{c}=\text { garis netral } \\
& \mathrm{I}=\text { Inersia }=1 / 12 . \mathrm{b} \cdot \mathrm{h}^{3}
\end{aligned}
$$

Untuk benda uji tanpa tulangan bambu, nilai garis netral penampang, $y=1 / 2$. h. Sehingga persamaan di atas dapat disederhanakan sebagai berikut

Sehingga

$$
F l t=\frac{3 . P . L}{2 \cdot b \cdot h^{2}}
$$

$$
P_{\text {teoritis }}=\frac{2 \cdot b \cdot h^{2} \cdot F l t}{3 . L}
$$

Keterangan :
$F l t=$ kuat lentur (uji terdahulu)
$P=$ beban maksimum yang mengakibatkan
keruntuhan balok uji
$\mathrm{L}=$ panjang bentang diantara kedua balok

tumpuan, dalam $\mathrm{mm}$

$\mathrm{b}=$ lebar balok rata-rata, dalam $\mathrm{mm}$

$\mathrm{h}=$ tinggi balok rata-rata, dalam $\mathrm{mm}$.

$\mathrm{y}=$ garis netral diagram

Adapun untuk benda uji dengan penambahan tulangan bambu, nilai $\mathrm{P}$ teoritis diperoleh dari pendekatan skema diagram penampang pada balok beton bertulang sebagaimana pada gambar 2, yang diuraikan sebagai berikut.

$$
\begin{aligned}
& \mathrm{a}=\frac{A s \cdot F y}{0,85 \cdot f c \cdot b}, \mathrm{c}=0,85 \cdot \mathrm{a} \\
& \mathrm{Mn}=\text { As.Fy }(\mathrm{d}-\mathrm{a} / 2) \\
& \mathrm{M}=1 / 4 . \mathrm{P} \cdot \mathrm{L} \\
& \quad \rightarrow \text { P teoritis }=\frac{4 \cdot M n}{L}
\end{aligned}
$$

Dimana:

$$
\begin{aligned}
& \text { As = Luas selimut tulangan bambu } \\
& \mathrm{Fy}=\text { Kuat geser bambu (uji pull out) } \\
& \mathrm{Fc}=\text { kuat tekan papan eceng gondok } \\
& \mathrm{b}=\text { Lebar penampang benda uji }
\end{aligned}
$$

\section{Prosedur Pengujian}

Prosedur pengujian kuat lentur benda uji ini menggunakan tata cara pengujian sesuai SNI 03-4154-tahun 1996. Kuat lentur benda uji dilaksanakan dengan memakai alat uji tekan konvensional. Lokasi beban diletakkan di tengah benda uji dan di bawahnya diberi alat dial gauge untuk mencatat defleksi yang terjadi. Pembebanan dilakukan dengan interval tertentu dan pencatatan defleksi menyesuaikan interval beban tersebut. Penambahan beban (P) dilakukan secara terus menerus sampai benda uji mengalami keruntuhan. Metode pengujian disajikan seperti pada gambar berikut.

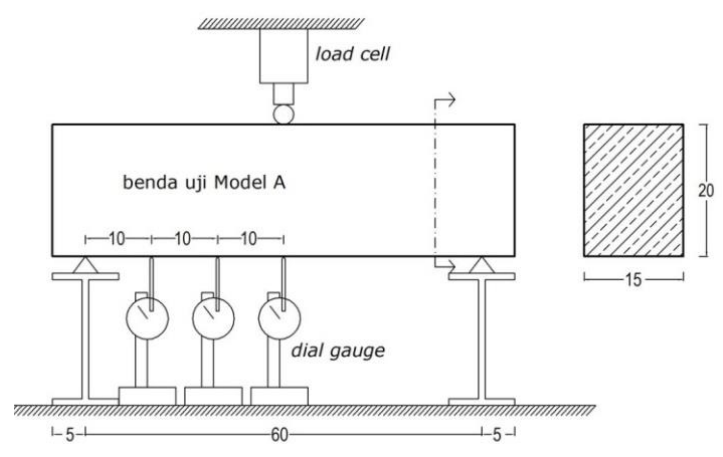

Gambar 3. Setting pengujian 1 


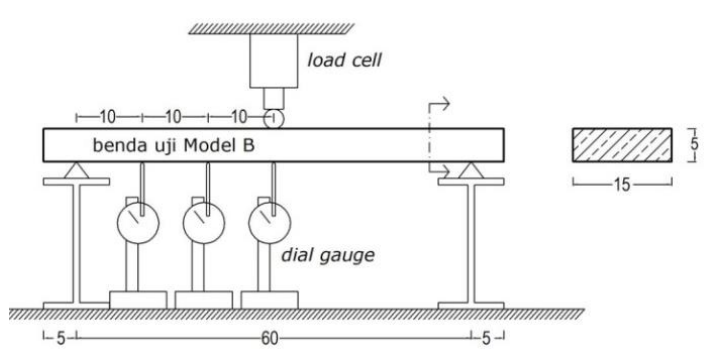

Gambar 4. Setting pengujian 2

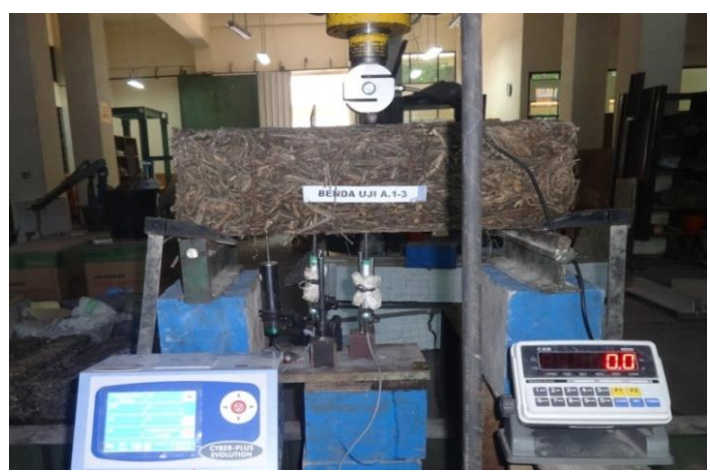

Gambar 5. Foto pengujian

\section{HASIL DAN PEMBAHASAN}

\section{Hasil Pengujian}

Hasil dari pengujian benda uji elemen balok (Model A) berupa data interval beban $(\mathrm{P})$ dan lendutan $(\Delta)$ dimasukkan dalam tabel 1 , untuk kemudian dianalisa lebih lanjut.

Dari data beban $(\mathrm{P})$ dan lendutan $(\Delta)$ hasil penelitian juga dibuat grafik hubungannya. Dari grafik ini terlihat bahwa dengan adanya penambahan tulangan bambu pada material panel semen eceng gondok mengakibatkan material lebih kuat dalam menahan beban (P) yang berarti semakin tinggi kuat lenturnya.

Adanya penambahan tulangan bambu pada material panel semen eceng gondok bekerja secara efektif dalam meningkatkan kuat lentur.

Dari pengujian laboratorium terlihat bahwa saat terjadi keruntuhan material, tulangan bambu tidak mengalami putus tarik. Hal ini mengindikasikan bahwa lekatan (bonding) antara tulangan bambu dan mortar semen eceng gondok merupakan bagian yang terlemah, yang perlu untuk diteliti lebih lanjut.

Adapun hasil dari pengujian benda uji elemen plat (Model B) berupa data interval beban $(\mathrm{P})$ dan lendutan $(\Delta)$ dimasukkan dalam tabel 2.
Tabel 1.Rekapitulasi P- $\Delta$ (Model A)

\begin{tabular}{cccc}
\hline \multirow{2}{*}{$\begin{array}{c}\text { Beban- } \\
\mathrm{P}\end{array}$} & \multicolumn{3}{c}{ Lendutan $-\Delta(\mathrm{mm})$} \\
\cline { 2 - 4 }$(\mathrm{kg})$ & $\begin{array}{c}\text { Tanpa } \\
\text { tulangan } \\
\text { bambu }\end{array}$ & $\begin{array}{c}\text { Tulangan } \\
\text { bambu } \\
\rho=0,006\end{array}$ & $\begin{array}{c}\text { Tulangan } \\
\text { bambu } \\
\rho=0,01\end{array}$ \\
\hline 0 & 0 & 0 & 0 \\
3 & 0,66 & 0,597 & 0,329 \\
6 & 2,138 & 1,408 & 0,963 \\
9 & 6,365 & 3,091 & 0,889 \\
12 & 9,79 & 4,715 & 2,805 \\
15 & 14,474 & 6,851 & 3,827 \\
18 & 20,188 & 8,773 & 5,134 \\
21 & 25,899 & 11,104 & 6,668 \\
24 & 36,83 & 13,362 & 8,577 \\
27 & & 16,187 & 10,117 \\
30 & & 18,797 & 12,583 \\
33 & & 22,064 & 14,135 \\
36 & & 23,196 & 16,126 \\
39 & & 25,647 & 19,847 \\
42 & & 28,628 & 20,988 \\
45 & & 30,629 & 23,144 \\
48 & & 33,477 & 27,055 \\
51 & & 36,929 & 27,87 \\
54 & & 39,438 & 30,085 \\
57 & & 42,85 & 32,755 \\
60 & & 47,873 & 35,398 \\
63 & & 51,003 & 37,93 \\
66 & & & 41,698 \\
69 & & & 42,511 \\
72 & & & 43,868 \\
75 & & & 44,012 \\
\hline
\end{tabular}

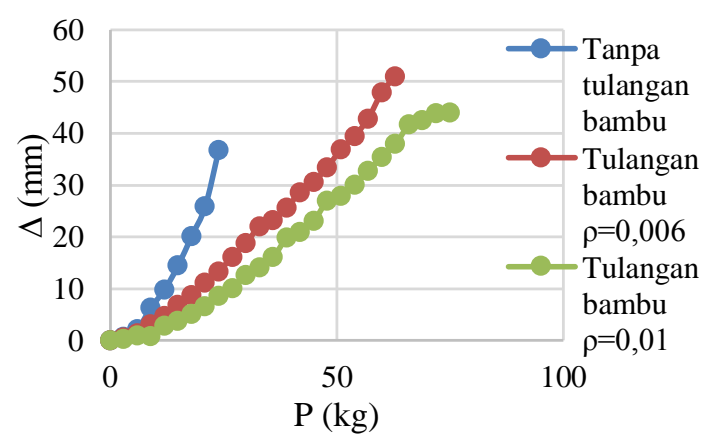

Gambar 6. Grafik hubungan P- $\Delta$ (Model A)

Tabel 2.Rekapitulasi P- $\Delta$ (Model B)

\begin{tabular}{cccc}
\hline \multirow{2}{*}{$\begin{array}{c}\text { Beban- } \\
\mathrm{P}\end{array}$} & \multicolumn{3}{c}{ Lendutan $-\Delta(\mathrm{mm})$} \\
\cline { 2 - 4 }$(\mathrm{kg})$ & $\begin{array}{c}\text { Tanpa } \\
\text { tulangan }\end{array}$ & $\begin{array}{c}\text { Tulangan } \\
\text { bambu }\end{array}$ & $\begin{array}{c}\text { Tulangan } \\
\text { bambu } \\
\rho=0,006\end{array}$ \\
\hline 0 & 0 & 0 & 0,01 \\
\hline 3 & 10,822 & 5,496 & 0 \\
6 & & 14,203 & 7,343 \\
9 & & 24,676 & 15,585 \\
12 & & 35,972 & 21,76 \\
15 & & 48,38 & 30.41 \\
18 & & & 38.217 \\
21 & & & 42,828 \\
\hline
\end{tabular}




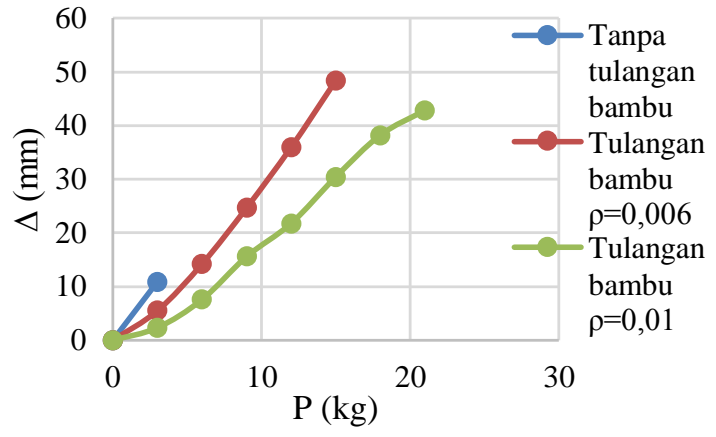

Gambar 7. Grafik hubungan P- $\Delta$ (Model B)

\section{Hubungan Momen dan kelengkungan}

Untuk menghitung kekakuan lentur benda uji (EI) menggunakan formula (1), sedangkan untuk kelengkungan $\left(\varphi=\frac{d^{2} y}{d x^{2}}\right)$ dan $\operatorname{momen}(M=$ $\varphi . E I)$. Hasil perhitungan EI, $\varphi$ dan M pada benda uji elemen balok (model A) secara ringkas dimasukkan dalam tabel 3. Adapun hasil perhitungan EI, $\varphi$ dan $\mathrm{M}$ pada benda uji elemen plat (model B) secara ringkas dimasukkan dalam tabel 4.

Tabel 3.Rekapitulasi M- $\varphi$ (Model A)

\begin{tabular}{ccccccc}
\hline $\mathrm{P}(\mathrm{kg})$ & $\Delta_{1}(\mathrm{~mm})$ & $\Delta_{2}(\mathrm{~mm})$ & $\Delta_{3}(\mathrm{~mm})$ & $\mathrm{El}\left(\mathrm{N} . \mathrm{mm}^{2}\right)$ & $\varphi(1 / \mathrm{mm})$ & $\mathrm{M}(\mathrm{N} . \mathrm{mm})$ \\
\hline 0 & 0,000 & 0,000 & 0,000 & - & - & 0 \\
3 & 0,173 & 0,232 & 0,336 & 4.017 .857 & 0,0000 & 83,57143 \\
6 & 0,575 & 0,776 & 1,140 & 2.368 .421 & 0,0001 & 172,4211 \\
9 & 1,491 & 2,108 & 3,095 & 1.308 .562 & 0,0002 & 258,3102 \\
12 & 3,179 & 4,477 & 6,815 & 792.370 & 0,0005 & 370,5121 \\
15 & 4,083 & 5,883 & 9,157 & 737.141 & 0,0007 & 482,6799 \\
18 & 6,155 & 8,718 & 13,944 & 580.895 & 0,0010 & 607,1515 \\
21 & 10,300 & 14.071 & 22,897 & 412.718 & 0,0018 & 728,5295 \\
24 & 14,150 & 19,686 & 31,015 & 348.219 & 0,0023 & 788,9937 \\
27 & 18.802 & 26,065 & 40,879 & 297.219 & 0,0030 & 880,5993 \\
\hline $\mathrm{L}=$ & 600 & $\mathrm{~mm}$ & & & & \\
$\lambda=$ & 100 & $\mathrm{~mm}$ & & & & \\
$\mathrm{~b}=$ & 150 & $\mathrm{~mm}$ & & & & \\
$\mathrm{~d}=$ & 155 & $\mathrm{~mm}$ & & & &
\end{tabular}

Tabel 4.Rekapitulasi M- $\varphi$ (Model B)

\begin{tabular}{ccccccc}
\hline $\mathrm{P}(\mathrm{kg})$ & $\Delta_{1}(\mathrm{~mm})$ & $\Delta_{2}(\mathrm{~mm})$ & $\Delta_{3}(\mathrm{~mm})$ & $\mathrm{El}\left(\mathrm{N} . \mathrm{mm}^{2}\right)$ & $\varphi(1 / \mathrm{mm})$ & $\mathrm{M}(\mathrm{N} . \mathrm{mm})$ \\
\hline 0 & 0,000 & 0,000 & 0,000 & - & - & 0 \\
1 & 1,095 & 1,052 & 1,675 & 268.657 & 0,0001 & 33,47463 \\
2 & 2,420 & 2,387 & 4,097 & 219.673 & 0,0003 & 75,12814 \\
3 & 4,563 & 4,943 & 7,553 & 178.737 & 0,0005 & 93,30068 \\
3.5 & 6,893 & 8,318 & 12,029 & 130.934 & 0,0007 & 97,1789 \\
\hline $\mathrm{L}=$ & 600 & $\mathrm{~mm}$ & & & & \\
$\lambda=$ & 100 & $\mathrm{~mm}$ & & & & \\
$\mathrm{~b}=$ & 150 & $\mathrm{~mm}$ & & & & \\
$\mathrm{~d}=$ & 40 & $\mathrm{~mm}$ & & & & \\
\hline
\end{tabular}

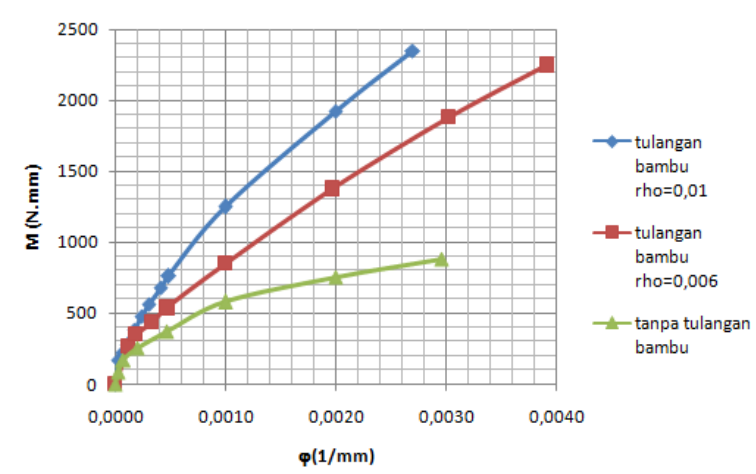

Gambar 8. Grafik hubungan M- $\varphi$ (Model A)

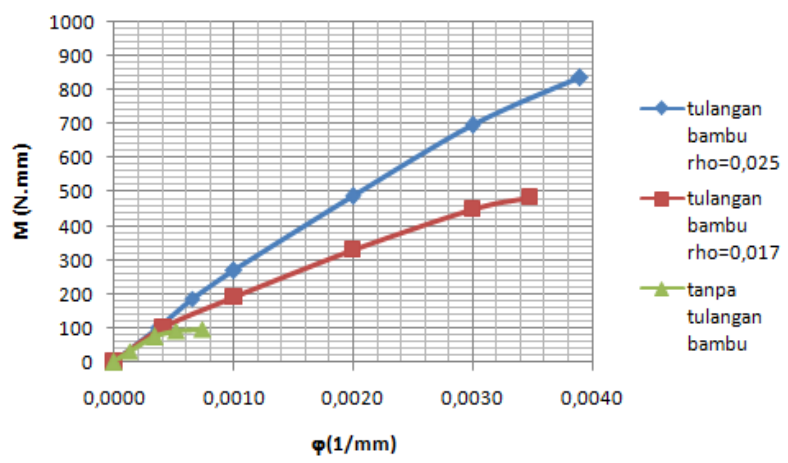

Gambar 9. Grafik hubungan M- $\varphi$ (Model B) 


\section{Kuat Lentur}

Dengan menggunakan formula (4) untuk benda uji tanpa tulangan bambu dan formula (5) untuk benda uji menggunakan tulangan bambu, dapat digunakan sebagai parameter untuk menghitung kuat lentur (P teoritis).

Hasil perhitungan (P teoritis) ini kemudian akan dibandingkan dengan $\mathrm{P}$ maks (hasil pengujian di laboratorium. Secara ringkas dijelaskan pada tabel 5 dan gambar 10.

Dari grafik kuat lentur benda uji model balok (model A) terlihat bahwa penambahan tulangan bambu menyebabkan kuat lentur panel semen eceng gondok semakin meningkat.
Perhitungan secara teoritis dan hasil pengujian di laboratorium menunjukkan proporsionalitas penelitian yang cukup baik.

Untuk benda uji model plat (Model B), hasil penelitian disajikan pada tabel 6 dan gambar 11.

Dari grafik kuat lentur benda uji model plat (model B) terlihat bahwa penambahan tulangan bambu menyebabkan kuat lentur panel semen eceng gondok semakin meningkat. Perhitungan secara teoritis dan hasil pengujian di laboratorium menunjukkan proporsionalitas penelitian yang cukup baik

Tabel 5. Rekapitulasi kuat lentur, P (Model A)

\begin{tabular}{ccccccc}
\hline \multirow{2}{*}{ Benda Uji } & \multicolumn{7}{c}{$\mathrm{P}(\mathrm{kg})$} \\
\cline { 2 - 7 } & \multicolumn{2}{c}{ Tanpa tulangan bambu } & \multicolumn{2}{c}{ Tulangan bambu $\rho=0,006$} & \multicolumn{2}{c}{ Tulangan bambu $\rho=0,01$} \\
\cline { 2 - 7 } & $\mathrm{P}_{\max }$ & $\mathrm{P}_{\text {teoritis }}$ & $\mathrm{P}_{\max }$ & $\mathrm{P}_{\text {teoritis }}$ & $\mathrm{P}_{\max }$ & $\mathrm{P}_{\text {teoritis }}$ \\
\hline 1 & 27 & 41,04 & 63 & 58,01 & 80 & 90,147 \\
2 & 21 & 41,04 & 48 & 58,01 & 66 & 90,147 \\
3 & 24 & 41,04 & 66 & 58,01 & 71 & 90,147 \\
\hline Rata-rata & 24 & 41,04 & 59 & 58,01 & 72,33 & 90,15 \\
\hline
\end{tabular}

Tabel 6. Rekapitulasi kuat lentur, P (Model B)

\begin{tabular}{ccccccc}
\hline \multirow{3}{*}{ Benda Uji } & \multicolumn{7}{c}{$\mathrm{P}(\mathrm{kg})$} \\
\cline { 2 - 7 } & \multicolumn{2}{c}{ Tanpa tulangan bambu } & \multicolumn{2}{c}{ Tulangan bambu $\rho=0,017$} & \multicolumn{2}{c}{ Tulangan bambu $\rho=0,025$} \\
\cline { 2 - 7 } & $\mathrm{P}_{\max }$ & $\mathrm{P}_{\text {teoritis }}$ & $\mathrm{P}_{\max }$ & $\mathrm{P}_{\text {teoritis }}$ & $\mathrm{P}_{\max }$ & $\mathrm{P}_{\text {teoritis }}$ \\
\hline 1 & 3,5 & 2,55 & 15 & 8,378 & 23,5 & 10,608 \\
2 & 3 & 2,55 & 17 & 8,378 & 21 & 10,608 \\
3 & 3,5 & 2,55 & 17 & 8,378 & 21 & 10,608 \\
\hline Rata-rata & 3,33 & 2,55 & 16,33 & 8,38 & 21,83 & 10,61 \\
\hline
\end{tabular}

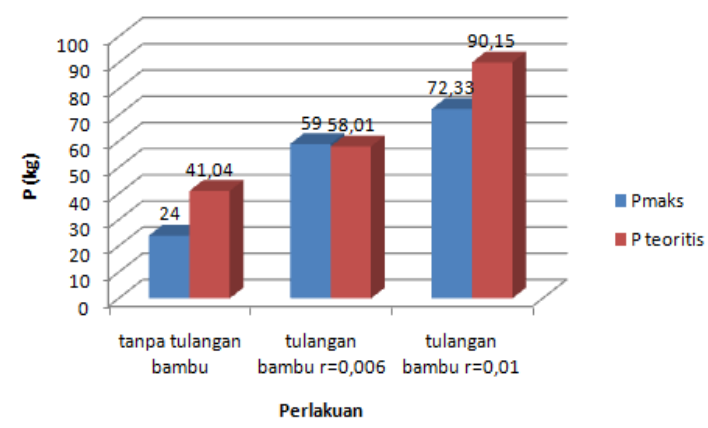

Gambar 10. Grafik kuat lentur, P (Model A)

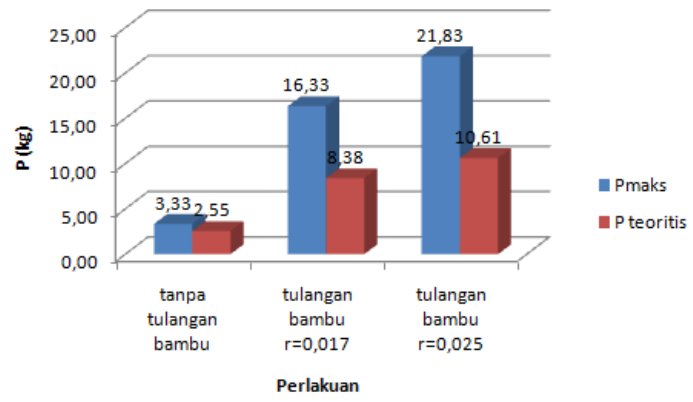

Gambar 9. Grafik kuat lentur, P (Model B)

\section{Uji Statistik}

Dengan menggunakan analisa statistik ANOVA (Analysis of Variance) 1 arah diperoleh nilai Fhitung $(=36,81)$ lebih besar dari Ftabel $(5 \%=5,14$ dan $1 \%=10,92)$ untuk benda uji elemen balok (model A). Sedangkan nilai Fhitung $(=232,07)$ lebih besar dari Ftabel $(5 \%=5,14$ dan $1 \%=10,92)$ untuk benda uji elemen plat (model B).

Sehingga hipotesa Ho ditolak dan $\mathrm{H} 1$ diterima, dimana;

Ho = Tidak ada perbedaan kuat lentur papan semen eceng gondok dengan berbagai variasi penambahan tulangan bambu $(\mathrm{A} 1=\mathrm{A} 2=\mathrm{A} 3$ dan $\mathrm{B} 1=\mathrm{B} 2=\mathrm{B} 3)$.

$\mathrm{H} 1$ = Ada perbedaan (pengaruh) kuat lentur papan semen eceng gondok dengan berbagai variasi penambahan tulangan bambu $(\mathrm{A} 1 \neq \mathrm{A} 2 \neq \mathrm{A} 3$ dan $\mathrm{B} 1 \neq \mathrm{B} 2 \neq \mathrm{B} 3)$. 


\section{KESIMPULAN DAN SARAN}

\section{Kesimpulan}

- Dari grafik hubungan P- $\Delta$ terlihat bahwa dengan adanya penambahan tulangan bambu pada material panel semen eceng gondok menyebabakan penurunan lendutan benda uji (kekakuan semakin meningkat).

- Hasil pengujian pada benda uji model penampang balok (model $\mathrm{A}$ ) dengan rasio tulangan bambu $\rho=0, \rho=0,006$ dan $\rho=0,01$ kuat lenturnya adalah $\mathrm{P}=24 \mathrm{~kg}, \mathrm{P}=59 \mathrm{~kg}$ dan $\mathrm{P}=72 \mathrm{~kg}$. Untuk model penampang plat (model B) dengan rasio tulangan bambu $\rho=0, \rho=0,017$ dan $\rho=0,025$ kuat lenturnya adalah $\quad \mathrm{P}=3,33 \mathrm{~kg}, \quad \mathrm{P}=16,33 \mathrm{~kg} \quad$ dan $\mathrm{P}=21,83 \mathrm{~kg}$. Penambahan tulangan bambu pada material papan semen eceng gondok menyebabkan kenaikan kuat lenturnya.

- Dari uji statistik untuk benda uji elemen balok (model A) diperoleh nilai Fhitung = 36,816 lebih besar dari Ftabel $=5,14$ $(\alpha=5 \%)$ dan Ftabel $=10,92 \quad(\alpha=1 \%)$. Adapun untuk benda uji elemen plat (model B) nilai Fhitung $=232$, lebih besar dari Ftabel $=5,14(\alpha=5 \%)$ dan Ftabel $=$ $10,92(\alpha=1 \%)$. Jadi terlihat adanya pengaruh penambahan tulangan bambu terhadap kuat lentur papan semen eceng gondok $\left(\mathrm{F}_{\text {hitung }}>\mathrm{F}_{\text {tabel }}\right)$

\section{Saran}

- Perlunya dibuat berbagai variasi model dan pola penulangan bambu terhadap material papan semen eceng gondok untuk mendapatkan penulangan yang lebih optimal.

- Perlu dilakukan uji tarik (pull out) tulangan bambu terhadap papan semen eceng gondok.

- Perlunya dibuat benda uji dalam skala penuh untuk mendapatkan data yang lebih akurat.

- Untuk penelitian selanjutnya, perlu memeriksa terlebih dahulu properti material panel semen eceng gondok simultan dalam satu waktu saat pembuatan benda uji.

\section{DAFTAR PUSTAKA}

Agustin D L, Sri Murni Dewi, Wisnumurti, 2015, Pengaruh Penambahan Kait Pada Tulangan Bambu Terhadap Respon Lentur Balok Beton Bertulangan Bambu, Jurnal Rekayasa Sipil/Volume 9, No 2, Univ. Brawijaya Malang

Amir, A.H. 2002, Pemanfaatan Limbah Kayu Untuk Bahan Bangunan (Laporan Proyek), Pusat Penelitian dan Pengem bangan Permukiman, Departemen Pekerjaan Umum, Bandung.

Andriati, A.H. 2000, Pemanfaatan Limbah Untuk Bahan Bangunan (Laporan Proyek), Pusat Penelitian dan Pengembangan Permukiman, Departemen Pekerjaan Umum, Bandung.

ASTM C423-90a, Standar Pengujian Akustik.

Ghavani, K.,1990, Aplication of Bamboo as a lowcostConstruction Material: 270-279. In Rao,I.V.R., Gnanaharan, R. \& Shastry, C.B.,Bamboos Current Research, The KeralaForest Research Institute-India, and IDRC, Canada.

Morisco, 2006, Pemberdayaan Bambu untuk Kesejahteraan Rakyat dan Kelestarian Lingkungan, Pidato Pengukuhan Guru Besar Fakultas Teknik Univ. Gajahmada, Yogyakarta

Moslemi AA, 1989, Correlation Between Wood Cement Compatibility and Wood ExtractivesForest Product Journal 39(6) : 55-58, New York

Neville, A.M. 1981, Properties of Concrete, Longman Scientific\& Technical, New York.

Pathurahman, Jauhar Fajrin.2003 .Aplikasi Bambu Pilinan Sebagai Tulangan BalokBeton. Jurnal Dimensi Teknik Sipil Vol 5, No. 1, Maret 2003: 39 - 44. Univ. Kristen Petra. Surabaya

Popov, E.P, 1984, Mekanika Teknik (terjemahan), Penerbit Erlangga, Jakarta

R Park \& T Paulay, 1975, Reinforced Concrete Structures, John Willey \& Sons Inc, Canada

Simatupang. 1974. Pembuatan dan Penggunaan Campuran Semen dan Kayu Sebagai Bahan Bangunan. Kehutanan Indonesia. PP 390-392

SNI SNI 03-4154-1996, Metode Pengujian Kuat Lentur Beton dengan Balok Uji Sederhana yang Dibebani Terpusat Langsung. 